\title{
O bstáculos históricos à vida democrática em Portugal e no Brasil
}

\author{
FÁBIO KONDER COMPARATO
}

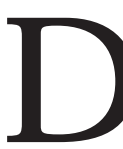

ESDE A Antigüidade Clássica até a segunda metade do século XIX, a democracia sempre foi tida, entre os pensadores políticos, como um regime político subversor da hierarquia social. M ontesquieu sustentava que, numa sociedade democrática, as mulheres, as crianças e os escravos já não se submeteriam a ninguém; não haveria mais bons costumes, amor à ordem, virtude enfim ${ }^{1}$. James $M$ adison, por sua vez, sublinhou que a democracia, por ele entendida como "a sociedade consistente num pequeno número de cidadãos que se reúnem e administram o governo diretamente", incentivaria o espírito de facção, pondo em constante risco a ordem social ${ }^{2}$.

No mundo contemporâneo, contudo, o juízo de valor que se faz sobre a democracia é exatamente o inverso. Com raras exceções, já nenhum partido ou movimento político ousa dizer-se antidemocrático. Todos, ao contrário, esforçam-se por se apresentar como os únicos verdadeiros defensores do "governo do povo, pelo povo e em prol do povo".

Essa unanimidade atual, construída em torno do conceito de democracia, é evidentemente suspeita. Ela revela, sem sombra de dúvida, uma formidável confusão semântica, ao fazer do elogio universal do regime democrático um simples chavão do jogo político. o povo, que afinal, pelo próprio sentido etimológico, seria o principal beneficiário dessa forma de organização política, parece ter sérias dificuldades em entender, exatamente, o que está por trás das palavras encantatórias da propaganda. N uma pesquisa realizada em 1999 com mais de cinqüenta mil pessoas em sessenta países, citada no R elatório das $\mathrm{N}$ ações U nidas de 2002 sobre o D esenvolvimento H umano, apurou-se que apenas dez por cento dos entrevistados reconheceram que o governo do seu país obedecia à vontade do povo ${ }^{3}$.

O ra, Portugal e Brasil - que sofreram durante o último século regimes auto ritários e ditatoriais por dezenas de anos - têm hoje o seu Estado organizado segundo o vigente padrão consensual do regime democrático: ambos contam com governantes eleitos pelo voto popular, em pleitos livres e multipartidários, e ostentam uma separação formal de Poderes. M as seria esta, efetivamente, a percepção que os nossos povos têm do regime político em vigor? Reconheceriam 
eles, contra a maioria esmagadora dos consultados na pesquisa mencionada, que os seus respectivos governos cumprem, zelosamente, os ditames da vontade popular?

A indagação parece pertinente e importante, se se quiser sair do terreno pantanoso das ficções políticas. 0 que se pretende trazer aqui, neste breve excurso, não é evidentemente uma resposta cabal à pergunta, mas apenas al guns elementos de reflexão sobre a matéria.

Comecemos, segundo a boa lógica, por precisar os conceitos.

\section{D emocracia e Feudalismo: o conteúdo histórico dos conceitos}

\section{Democracia: voltando às ori gens}

U $m$ dos grandes princípios metodológicos das ciências humanas é o do caráter histórico dos conceitos. N esse vasto campo do saber, os conceitos não refletem, como em matéria de ciências exatas, a essência abstrata e invariável da realidade; eles exprimem antes, de modo sintético, determinada experiência histórica.

Temos, pois, que, para examinar o caráter democrático ou não da vida política portuguesa e brasileira, é indispensável cotejá-la com o modelo de democracia criado originalmente em determinado momento histórico, e ao qual todos os desenvolvimentos ulteriores se referem. Esse modelo é, incontestavelmente, o regime ateniense de governo popular, que durou pouco mais de dois séculos (de 501 a 338 a.C.).

A classificação dos regimes políticos, no pensamento grego clássico, adotou desde cedo, como critério de ordem, o número de titulares da soberania ou poder político supremo (kyrion). De acordo com esse critério, reconheceu-se a existência de três grandes regimes primários, conforme o poder supremo fosse atribuído a uma só pessoa, a poucos cidadãos ou a todos eles ${ }^{4}$. Cada um desses modelos, por sua vez, comportava uma modalidade pura, em que o titular do poder supremo governava em vista do bem comum, e outra correspondente modalidade degenerada, na qual o soberano, de modo exclusivo ou preferencial, exercia o poder no seu próprio interesse. Teríamos, assim, em contraposição à realeza, a tirania; como degeneração da aristocracia (em que o poder supremo pertence aos melhores, aristoi ), a oligarquia (soberania dos ricos); e, finalmente, como desvio daquele que, à míngua de um termo específico, Aristóteles denominava genericamente organização ou constituição política (politéia), a democracia5.

No tocante à diferença entre oligarquia e democracia, Aristóteles insistiu na necessidade de se analisar a realidade "com o método filosófico" (methodos philosophounti), o que significa, segundo a lição que o estagirita recolheu de seu mestre Platão, buscar a essência das coisas, sem se contentar com o simples aspecto prático (memonon apobleponti prosto pratteo); ou seja, satisfazendo-se com a mera a aparência. A oligarquia, observou ele, ao contrário do que o sentido literal da palavra insinua, não é propriamente o regime político em que a sobera- 
nia pertence a poucos, mas sim aquele em que os titulares do poder supremo formam a classe rica ("os que têm riqueza", oi tasoussias ekhontes); ao passo que, na democracia, so berana é a classe dos pobres (aporoi ), ou, segundo uma fórmula eufêmica, osque "não possuem muitos bens" (oi mekektemenoi plethosoussias) ${ }^{6}$.

É evidente que essa classificação dos regimes políticos conforme ao número de detentores da soberania significa, implicitamente, o reconhecimento de que há uma escala decrescente de concentração de poderes pessoais, da monarquia à oligarquia e desta à democracia. O ra, tanto Platão como Aristóteles, fiéis à sua concepção de que a realidade ética deve ser considerada conjuntamente pelo aspecto objetivo e subjetivo (as instituições e os homens), e aplicando a cada um dos regimes políticos a sua visão contraditória ou dialética entre a boa e a má modalidade, entendem que o melhor (ou "mais divino": the otatos) ${ }^{7}$ de todos os regimes é a realeza. Todavia, como a corrupção do ótimo é sempre o péssimo ${ }^{8}$, a tirania é, de modo correspondente, o pior deles. O u seja, quanto maior a concentração pessoal de poder político, mais deletério se torna para a póliso exercício desse poder no interesse do próprio titular.

$D$ aí decorre que, para Aristóteles, a democracia é o menos maléfico dos maus regimes, ou, como prefere qualificar o filósofo, o mais moderado (metriotatos) deles ${ }^{9}$. N essa mesma linha de análise, sustentou também que a politéa, por ele classificada entre as boas formas de organização política, nada mais seria do que um misto de oligarquia e democracia, com predominância das instituições democráticas ${ }^{10}$.

Em suma, no pensamento do grande estagirita, se o ótimo é inimigo do bom, se não se pode organizar a pólis da melhor maneira para propiciar a felicidade geral, é preferível optar por uma constituição em que se reduza ao máximo a possibilidade de abuso de poder. E essa constituição é, inequivocamente, a de natureza democrática, pois nela, ao deter cada cidadão igual prerrogativa de participar diretamente da vida política, em especial o igual direito de manifestação nas assembléias do povo (isegoria), o eventual abuso de poder só se torna grave quando praticado conjuntamente pela maioria dos cidadãos. Contra essa eventualidade, de resto, a democracia ateniense dispunha de um antídoto eficaz: a soberania da lei (nomos), em lugar da soberania do demos. 0 sentido e a importância política que os clássicos atribuíam ao nomos eram incomparavelmente mais amplos e profundos que os conferidos pela lei moderna. J uridicamente, tratava-se muito mais de uma norma de nível constitucional, irreformável pelo povo, do que de uma lei ordinária.

Além disso, o poder dos governantes, pelo menos na democracia praticada em Atenas por mais de dois séculos, foi estritamente limitado por um complexo de instituições de cidadania ativa, graças às quais o povo, pela primeira vez na $\mathrm{H}$ istória, pôde governar-se a si mesmo. As grandes decisões políticas - a introdução de novas leis, a declaração de guerra, a conclusão de tratados de paz ou de aliança - eram tomadas diretamente pelo conjunto dos cidadãos reunidos na 
Ekkléria. E quanto aos órgãos do que chamamos hoje Poder Executivo, eles eram singularmente fracos: os principais dirigentes políticos, os estrategos, deviam ter suas funções confirmadas, todos os meses, pelo Conselho (Boulê).

Por isso mesmo, como reconheceu Aristóteles, a democracia é o regime em que se garante a maior liberdade e a maior igualdade de todos os cidadãos ${ }^{11}$.

o que o filósofo, porém, não discutiu, foi a questão que ocupa, hoje, um lugar central na análise política e que, efetivamente, domina to do o debate sobre a possibilidade de eficiente funcionamento das instituições democráticas em países subdesenvolvidos: - a igualdade básica de condições sociais de vida é um pressuposto de existência da democracia, ou, diversamente, representa um objetivo a ser alcançado pelo regime no curso do tempo?

\section{Feudali smo e senhori i na I dade Médi a: a di sti nção necesária}

O mesmo cuidado metodológico, lembrado acima para o uso do conceito de democracia, deve ser aplicado agora no tocante ao conceito de feudalismo.

É que este último, como bem advertiu um autor, tornou-se, desde os embates revolucionários contra o ancien régime, mais uma invectiva do que a designação geral de um sistema de instituições sociopolíticas ${ }^{12}$. O s líderes do movimento de 1789 assimilaram, abusivamente, o feudalismo à monarquia absoluta, quando, na verdade, as instituições feudais só puderam prosperar na E uropa na época de esfacelamento do Estado, conseqüente à extinção do I mpério Romano do $O$ cidente. A civilização feudal provocou, por conseguinte, o exato oposto de uma concentração do poder político: a sua fragmentação em to do o território da E uropa $O$ cidental.

A razão de ser desse desvio semântico foi uma lamentável confusão - a qual persiste de forma subentendida até hoje - entre feudalismo e senhorio, duas instituições que conviveram e se interligaram durante um certo período histórico, mas que eram perfeitamente distintas em suas origens e em sua estrutura.

O feudalismo organizou-se em torno da relação vassálica de natureza pessoal, fundada na homenagem (do latim bárbaro hominium ou homagium) e na fidelidade (fides), ao passo que o senhorio era simplesmente uma posição dominante sobre servos ou clientes, estribada na posse de terras. 0 senhor, além dos poderes econômicos decorrentes da propriedade, gozava ainda de prerrogativas políticas, como a jurisdição sobre todos os que viviam em suas terras, o direito de portar armas e o de cobrar tributos.

O pacto de vassalagem, celebrado entre duas pessoas livres, compreendia, de um lado, o reconhecimento da superioridade moral (reverentia) de uma delas sobre a outra e, em contrapartida, a obrigação de auxílio (militar e material) do superior ao inferior.

Conforme o grau de predominância de uma dessas instituições sobre a outra, a organização social como um todo recebeu um molde bem diverso. Enquanto na sociedade predominantemente feudal, as pessoas, embora em posição 
desigual, mantinham relações de direitos e deveres recíprocos, a sociedade predominantemente senhorial foi toda estruturada em torno do poder do proprietário, diante do qual não há propriamente sujeitos de direito, mas simples dependentes.

Temos, assim, que na organização feudal o rei é primus inter pares, não exercendo poder sobre os outros senhores do estamento nobre. E ra-lhe vedado, tal como numa organização federativa, invadir a esfera de competência territorial de cada titular de feudo. Philippe de Beaumanoir registrou, em sua compilação sobre o direito costumeiro vigente na baronia francesa de Beauvais, no século XI, que "cada barão é soberano em sua baronia", sendo "o rei soberano sobre todos" ${ }^{13}$. N o senhorio, em contraste, o proprietário não estava obrigado, no interior de seu domínio, a respeitar os direitos de ninguém. O s vilãos mantinham relações individuais com o senhor, do qual dependiam integralmente para a sua subsistência e, por isso, jamais conseguiram desenvolver relações de solidariedade entre si. Fora dos limites de suas terras, o titular do senhorio via, nos demais senhores, unicamente rivais, cujo apetite de conquista precisava ser sempre refreado.

O elemento histórico de ligação (e também de confusão) entre o contrato vassálico e o senhorio foi, sem dúvida, o fato de que o vassalo costumava receber do seu superior, para seu sustento e também para permitir-lhe suportar os ônus dos serviços de vassalagem, um feudo, isto é, a concessão de um bem patrimonial sob a forma de domínio útil, reservando-se o superior para si o domínio eminente. Esse feudo geralmente consistia num trato de terra, mas nem sempre: havia também "feudos de bolsa" ou "feudos-pensões", de natureza mobiliária. Seja como for, o contrato de vassalagem, em si, nada tinha de econômico. Ele só deu margem a lucros tardiamente, por incontestável desvio de seu sentido primitivo, com a transformação dos feudos em senhorios autônomos ${ }^{14}$.

$\mathrm{N}$ a verdade, os senhorios já existiam de há muito, antes de se iniciar a I dade M édia. O s latifundia romanos, que prosperaram em toda a extensão do império, eram posições de senhorio, no fundo e na forma. Com o enfraquecimento dos laços de vassalagem, os antigos feudos tornaram-se autênticos senhorios, os quais subsistiram ainda por vários séculos após o desaparecimento do feudalismo, e acabaram por transformar-se, com a abolição da servidão pessoal e a simplificação dos direitos reais, na propriedade rural regulada pelos $C$ ódigos do século XIX.

Foi justamente por confundir feudalismo com senhorio, que Karl M arx pôde sustentar que as relações feudais constituíram uma etapa intermédia entre 0 escravismo antigo e o capitalismo moderno. O ra, como a história de Portugal e de suas colônias no-lo confirma de modo cabal, o regime capitalista desde cedo transformou a antiga servidão da gleba, típica do regime de senhorio, em escravidão pura e simples, organizando-a empresarialmente na produção de gêneros agrícolas para o mercado. 
Seja como for, o que importa salientar para os propósitos desta exposição, é que, enquanto o feudalismo foi uma organização social de fracionamento e, em certa medida, de equilíbrio de poderes (confiram-se, por exemplo, as estipulações da M agna Carta de 1215), o senhorio rural, bem ao contrário, representou o modelo e a fonte de um tipo de organização política com absoluta concentração de todos os poderes na pessoa do titular do domínio.

\section{A formação da sociedade portuguesa e os obstáculos à vida democrática \\ Estrutura da sociedade portuguesa medieval}

$\mathrm{N}$ ão é preciso grande esforço de análise histórica para perceber que a sociedade portuguesa apresentou, durante todo o período crucial de formação na nacionalidade (1096-1325), características distintas, não só em relação às regiões européias situadas além dos Pirineus, como até mesmo em comparação com L eão e Castela. E as razões para tanto foram basicamente quatro, a saber:

1. predominância da posição senhorial sobre as relações feudo-vassálicas;

2. importância crescente da escravidão, relativamente à servidão territorial;

3. precoce concentração de poderes feudais e senhoriais na pessoa do rei;

4. marcada orientação mercantil da dominação político-social.

É inegável que, em Portugal, os vínculos de vassalagem sempre foram tênues, fragmentários e instáveis, e nunca chegaram a ligar os grandes senhores entre $\mathrm{si}^{15}$. R elações feudo-vassálicas só existiram, em plenitude, entre o rei e a nobreza. Foi o que levou alguns historiadores de vulto, a começar por Alexandre $\mathrm{H}$ erculano, a sustentar a tese extremada de que nunca houve autêntico feudalismo em Portugal ${ }^{16}$.

E $m$ contraste com essa debilidade das instituições propriamente feudais, 0 regime do senhorio sempre foi pujante em terras portuguesas. D eve-se observar que ele deita raízes na colonização romana da península, com a criação de múltiplos latifúndios atribuídos aos chefes militares como prêmio de campanha. É sabido que a Espanha foi a província mais romanizada do O cidente e, dentro dela, especialmente a Bética e as planícies da Lusitânia ${ }^{17}$.

Pois foi nesse largo espaço senhorial que se desenvolveu, muito antes das demais regiões da Europa, a escravidão ligada à agricultura. Assim é que, se os servos da gleba já eram uma categoria quase que totalmente extinta na época da fundação da nacionalidade portuguesa, a partir de meados do século XI o número de escravos mouros cresceu constantemente, na medida da progressiva reconquista do território ${ }^{18}$. 0 aumento constante da mão-de-obra escrava, obviamente, influiu poderosamente sobre o trabalho livre. É isto que explica a antecipada transformação dos pequenos lavradores, proprietários ou arrendatários, em assalariados agrícolas, quando se compara Portugal com as demais regiões ocidentais da Europa. Já em 1253, ao baixar o regimento dos preços, Afonso III impôs um 
tributo sobre os salários pagos a todos os trabalhadores agrícolas, o que denota a relativa importância da economia salarial à época ${ }^{19}$.

A economia fundada no trabalho escravo já existia há pelo menos dois séculos, quando a partir de 1444 iniciou-se o tráfico regular de negros africanos, o qual iria crescer extraordinariamente com o estabelecimento dos primeiros engenhos de açúcar no litoral brasileiro, na centúria seguinte. C om o incremento substancial da escravidão africana, o assalariado agrícola, que havia sido precocemente introduzido na península, quase que desapareceu.

Em pouco tempo, o tráfico de escravos africanos tornou-se uma das mais importantes fontes de receita para o tesouro régio, com a multiplicação de tributos de efeito cumulativo, denominados "donativos", "subsídios", "preferências", "alcavalas". Em 1473, as Cortes pedem ao monarca que estabeleça a proibição de levar para fora os negros oriundos da Guiné, porque só com eles se faziam terras novas, rompiam-se as matas e drenavam-se os pântanos ${ }^{20}$. M as 0 interesse pecuniário da Coroa, diretamente beneficiada pela arrecadação desses impostos, falou mais alto.

A terceira grande marca estrutural de formação da sociedade portuguesa foi a precoce concentração de poderes na pessoa do rei.

A verdadeira causa do fenômeno foi, sem dúvida, a guerra de reconquista territorial aos mouros, seguida pela luta de independência contra os espanhóis. O monarca português, desde cedo, assumiu as funções de chefe militar supremo, transformando os antigos nobres em comandados, dos quais exigia, mais que a fidelidade vassálica, a estrita obediência castrense.

Asssinale-se que as famo sas leis de A fonso II , de 1211, anteciparam pioneiramente na Europa a instituição da soberania monárquica, quer em relação à nobreza, quer perante a autoridade eclesiástica. 0 rei dispensa, nesses ditames, 0 plural majestático e fala na primeira pessoa, como um general comandante a dirigir-se aos seus subordinados.

0 rei era, também, naqueles primeiros tempos, o principal senhor de terras no reino. O s lucros da terra em cultura, como salientou um historiador, formavam a parte permanente e mais segura das rendas do soberano ${ }^{21}$. O s privilégios usufruídos pelos demais titulares de senhorios não se consideravam como fundados em direito próprio, mas como resultantes de atos gratuitos do rei, suscetíveis, por isso, de revogação. Foi o que fez D. João I, seguindo o alvitre de J oão das Regras, quando reconheceu o estado de dilapidação do seu patrimônio. As terras que ele havia cedido aos nobres (dentre eles o próprio Condestável do R eino), em recompensa pelos feitos militares na guerra contra os espanhóis, foram retrocedidas ao monarca mediante o estipêndio de um soldo permanente aos expropriados. $O$ mesmo fez D. D uarte, ao promulgar a L ei M ental. E ulteriormente, D. M anuel, com a reforma dos forais, avançou no mesmo sentido. Como se sabe, o sistema de doação de senhorios territoriais pelo monarca foi desde logo aplicado no Brasil, quando se resolveu superar a fase de economia extrativa 
da madeira e dar início ao empreendimento colonial pela exploração agrícola: foram as capitanias hereditárias.

Tudo isso contribuiu para moldar, duradouramente, a estrutura da sociedade portuguesa em torno do poder monárquico. Os senhores, em lugar de autênticos vassalos, ligados por um pacto de honra ao soberano, reconheceramse desde cedo como clientes deste, reproduzindo-se com isso a situação vigorante na sociedade romana em torno do latifundiário. Com a passagem do poder pessoal do rei ao poder impessoal do Estado moderno, a vel ha clientela tornouse burocrática, capturando para si empregos, rendas públicas ou privilégios de negócio.

O processo de centralização absoluta do poder político na pessoa do rei não se limitou, porém, a reduzir a autonomia dos nobres em seus respectivos senhorios. Ele se estendeu também à I greja. D esde o século XIII, instituiu-se o padroado, pelo qual o soberano se reservava o poder exclusivo de nomeação de párocos e abades, primeiro nas igrejas régias e em seguida em todas as igrejas e mosteiros que até então não tinham senhor conhecido. À mesma época, mais exatamente a partir de 1266, reduziu-se a liberdade de eleição de bispos, passando o monarca a ter influência direta sobre a sua nomeação.

U m último ponto a assinalar para a recapitulação do processo de reforço contínuo do poder monárquico, no quadro da organização política do Portugal medievo, é a limitação da autonomia dos concelhos, como órgãos de administração municipal. Desde o início, a criação de municípios dependeu do reconhecimento régio, estabelecendo-se a necessária contrapartida de sua sujeição ao poder do monarca ${ }^{22}$.

Com a conjugação de todos esses fatores, formou-se uma sociedade cujo equilíbrio orgânico pendia inteiramente da cúpula, em vez de se fundar na base; ou seja, o exato oposto da estrutura social que enseja o funcionamento do regime democrático.

Como conseqüência da predominante estrutura senhorial e dessa persistente macrocefalia política, nas sociedades ibéricas em geral, e na portuguesa em particular, como já foi tantas vezes observado, nunca houve coesão ou solidariedade na base. A ordem é sempre exaltada como valor supremo, mas trata-se de uma ordem que nada tem em comum com o kosmospitagórico, no seu sentido de ordenação harmônica do universo. A ordem naturalmente concebida pelos povos ibéricos corresponde à sujeição completa dos comandados aos comandantes, tanto na vida privada, como na pública. Vale dizer, uma relação de obediência análoga à que se estabelece no seio dos corpos militares. 0 princípio social unificador não foi nunca a colaboração em nível horizontal entre indivíduos, famílias e grupos sociais mais vastos, mas sim a dependência de uns em relação a outros na dimensão vertical da imposição de ordens, a exigir estrita e cega obediência. Daí a razão decisiva, como salientou com argúcia Sérgio Buarque de H olanda ${ }^{23}$, pela qual a histórica política dos povos ibéricos sempre oscilou entre a 
anarquia dissolvente e a rigidez mecânica do despotismo. $\mathrm{N}$ ão foi, pois, reconheça-se, por mera coincidência histórica que a companhia inaciana, fundada no lema da submissão ao chefe perinde ac cadaver, tenha sido concebida na mente de um ibérico.

\section{A monarquia portuguesa pósmedi eval e o capi talismo}

Encerrada prematuramente a I dade M édia portuguesa já em fins do século XIV - outra característica original da monarquia lusitana em comparação com os demais reinos do 0 cidente europeu - a organização política sofre a influência decisiva dos grandes empreendimentos marítimos, moldados em termos nitidamente capitalistas.

O monarca torna-se, desde logo, o primeiro mercador do reino. Ele é não só o maior negociante de escravos africanos e o monopolista da pimenta, como será, mais adiante, o beneficiário exclusivo do estanco do tabaco.

Sob D. João II, entre 1486, ano em que se fundou a C asa dos Escravos, departamento régio integrado à Casa da M ina e Tratos da Guiné, e 1493, registrou-se a entrada no reino de 3.589 escravos da Guiné, de propriedade da coroa. No século seguinte, em apenas três anos, de 1511 e 1513, passaram pela Casa dos Escravos, segundo as contas do Almoxarife, 1.265 escravos de ambos os sexos, pertencentes ao rei. E sses cativos, atribuídos em propriedade ao so berano, provinham umas vezes do negócio direto por conta dele com os negreiros indígenas, outras vezes de rendas cobradas em espécie. Assim é que, em 1510, foram arrematados os direitos de cobrança das rendas régias à razão de novecentos mil reais por ano, pagáveis em negros. 0 tráfico, de resto, era estritamente regulado pelo monarca em seu próprio benefício ${ }^{24}$.

A introdução em massa de escravos no país era imprescindível em razão da aguda carência de mão de obra agrícola, provocada pela aventura marítima. 0 rei sempre foi o principal interessado no negócio de exportação de escravos, notadamente para Castela. $\mathrm{N}$ o reinado de Afonso $\mathrm{V}$ as $\mathrm{C}$ ortes pediram para que fosse proibida a saída de cativos para o estrangeiro, pois a agricultura carecia agudamente de braços. 0 monarca rejeitou liminarmente a súplica, pois ela vinha contrariar os seus interesses patrimoniais ${ }^{25}$.

Com o progressivo enfraquecimento do comércio com o Extremo O riente, o império ultramarino português concentra-se no Atlântico Sul, onde Portugal exerceu, efetivamente, uma dominação econômica exclusiva, graças ao tráfico de africanos ${ }^{26}$. E ntre Angola e Brasil, teceu-se uma forte rede de interesses mercantis, sob a proteção política de Lisboa. Angola fornecia o grande e indispensável fator de produção para o tipo de agricultura desenvolvido no Brasil: o braço escravo. E a exclusividade desse fornecimento permitia, ao mesmo tempo, o controle de toda a economia em terras brasílicas. Entre a África O cidental e o Brasil estabeleceram-se, durante três séculos, fortes laços econômicos e políticos. 
Q uanto à malagueta, seu comércio não tardou a ser instituído monopólio da coroa, o que tornou o soberano português conhecido depreciativamente em toda a Europa como "o rei da pimenta", ou leR oi-Epicier, como disse Francisco I de D. M anuel, o Venturoso.

$\mathrm{N}$ a verdade, a febre especulativa já de há muito tomara conta dos nobres, empenhados em comprar habitualmente gêneros de consumo para revendê-los com lucro. 0 que fez com que, já nas Cortes de L eiria de 1372, os representantes dos povos os increpassem, todos eles, de mercadores e regatõe ${ }^{27}$. E embora persistisse bem viva a anima versão da plebe por todos os que, intitulando-se fidalgos, faziam da mercancia o seu modo de vida habitual, o pendor mercantil da nobreza, equiparável ao da burguesia, permaneceu inabalado nos séculos posteriores, tendo sido vivamente reacendido com a exploração colonial. $\mathrm{N}$ as colônias, aliás, a pretensa fidal guia confundia-se em regra com a riqueza pessoal. "Viver à lei da nobreza", segundo a expressão consagrada, significava, pura e simplesmente, ser homem de posses.

$\mathrm{N}$ os demais grupos e classes superiores da sociedade colonial, a cupidez praticamente não conhecia limites. Entre os governantes, fossem eles civis ou militares, era normal complementar os estipêndios ou soldos com toda sorte a de traficâncias e exações patrimoniais. E screvendo do Rio de Janeiro em 6 de novembro de 1710 ao D uque de Cadaval, Frei Francisco de M enezes observou: "Sua M ajestade deu liberdade aos governadores para nego ciarem [...] Até agora sempre governavam e negociavam, mas era com receio; sempre tinham mão em si, agora vão pondo isto em tais termos que já não há negócio senão o seu" ${ }^{28}$. D e onde a conhecida diatribe de Vieira no Sermão de Santo António aos Peixes: "Porque os grandes, que têm o mando das Cidades e das Províncias, não se contenta a sua fome de comer os pequenos um por um, ou poucos, a poucos, senão que devoram e engolem os povos inteiros". O u, de maneira mais incisiva, ao saudar em julho de 1640, o M arquês de M ontalvão, novo Vice-R ei do Brasil, que acabara de chegar à Bahia: "Perde-se o Brasil, senhor (digamo-lo em uma palavra) porque alguns ministros de Sua $M$ ajestade não vêm cá buscar nosso bem, vêm cá buscar nossos bens" 29 .

$\mathrm{N}$ em mesmo o clero fugia desse padrão mercantil de vida. A atuação dos clérigos no contrabando ou descaminho de ouro, diamantes e tabaco no Brasil colonial é bem sabida. E contraditoriamente, ao mesmo tempo em que se entregavam, contra a mais autorizada tradição eclesiástica, à faina mundana do trato comercial, os padres seculares e as diferentes ordens religiosas timbravam em invocar contra o Fisco o privilégio medieval da imunidade tributária. Q uando, em 1656, a C oroa baixou ordens estritas para que os religiosos assumissem a sua parte contributiva no pagamento dos impostos lançados para fazer face às despesas militares na campanha contra os holandeses no Brasil, a Câmara de Salvador queixou-se, em ofício apresentado a Sua M ajestade, que as ordens clericais, que possuíam na capitania vastas pro priedades agrícolas, abastecidas com gado e abun- 
dante escravaria, além de muitos engenhos de açúcar, persistiam na recusa do pagamento desses impostos, de tal maneira que o peso tributário recaía sobre o restante da população, já por demais onerada ${ }^{30}$.

$\mathrm{N}$ ão há dúvida de que o longo conúbio entre política e comércio em Portugal teve início na segunda metade do século XIV, antes mesmo do advento da dinastia de Aviz ao trono real, com a edição por D. Fernando - portanto quase três séculos antes de C romwell! - das leis destinadas a estimular a indústria nacional da navegação e do seguro marítimo. 0 apoio da burguesia do Porto e de Lisboa ao M estre d'A viz em 1385 - a primeira revolução burguesa no 0 cidente fez com que o soberano português passasse a gerir o reino como se fora a sua própria casa de comércio, empregando seus ministros como autênticos prepostos do estabelecimento régio.

O ra, é mais do que provável que o precoce nascimento e a rápida expansão do capitalismo em Portugal vincule-se à estrutura predominantemente senhorial da so ciedade durante toda a I dade $M$ édia. $N$ esse sentido, nunca é demais salientar que o capitalismo, ao contrário do sistema feudal, conduz inevitavelmente à concentração de poder na sociedade. Ao contrário, pois, do que comumente se pensa e divulga, o sistema capitalista, pela sua própria natureza, é visceralmente contrário ao funcionamento de um autêntico regime democrático, dado que a so berania do povo representa, em si mesma, a dispersão do poder político, inclusive e notadamente o de regulação das atividades econômicas no seio da coletividade.

Com a expansão colonial do reino, a figura do rei mercador vai sendo, pouco a pouco, substituída pela impessoalidade do Estado capitalista, empenhado diretamente na exploração em monopólio do comércio ultramarino. Enquanto a C orte ensejava, por vezes, à burguesia mercantil a compra do título de nobreza lembre-se que nas companhias de comércio pombalinas o titular de mais de dez ações tornava-se nobre de pleno direito - a classe senhorial como um todo abandonou sem pesar a antiga condição de vassalagem ao rei, para assumir a posição, muito mais lucrativa, de cliente do Estado monárquico e depois republicano. Em lugar dos tradicionais privilégios, surgem novas rendas de situação, fundadas em relações contratuais exclusivas e ligações pessoais com o estamento burocrático.

\section{O lamentável mal-entendi do da democracia representati va}

A partir de 1578, com o desastre de Alcácer Q uibir, tem início o longo período de agonia do poder real. As remissões experimentadas com a R estauração de 1640, ou o despotismo modernizante de Pombal, mal encobriram a fatalidade da moléstia: o país estava em vias de perder, definitivamente, o seu ponto de equilíbrio, tradicionalmente situado na cúpula do edifício social. $\mathrm{N}$ ão é à toa que a mentalidade popular deixou-se embalar, durante séculos, pelo mito consolador do sebastianismo: o herói nacional haveria de ressuscitar, como Cristo, para salvar o seu povo. 
Portugal entrou, assim, no século XIX inteiramente despreparado para enfrentar as transformações políticas e econômicas provocadas pela ascensão da idéia democrática e o desenvolvimento do capitalismo industrial. Faltava-Ihe 0 protagonista, capaz de levar avante a formidável empresa de modernização das estruturas sociais: uma burguesia voltada para o futuro, desafiadora do risco, bem preparada tecnologicamente e consciente de que o estado de miserabilidade em que se encontravam as massas proletárias era um empecilho à expansão do nível geral de consumo, sem a qual o sistema capitalista não pode subsistir.

$\mathrm{N}$ a verdade, a idéia de democracia representativa, introduzida na vida política pela vez primeira com a Revolução de 1820, não passou, para usarmos da expressão famosa de Sérgio Buarque de H olanda para o caso brasileiro, de "um lamentável mal-entendido" 31 . I maginou-se que o regime político, em que o povo soberano aceita exercer o poder por meio de representantes livremente escolhidos em eleições periódicas, podia funcionar numa sociedade marcada por profundas desigualdades e habituada há séculos a respeitar situações objetivas de poder sem reivindicar direitos civis e políticos. 0 resultado é que, nos breves momentos em que o sistema atuou, a vida política e administrativa desenrolou-se no equívoco. Sob a égide do empenho e do compadrio, o povo fingia votar, os deputados proclamavam-se legitimamente eleitos, os juízes confundiam dominação com justiça e os funcionários públicos recebiam estipêndios sem saber exatamente onde estava o bem público.

N uma sucessão de revoltas e proclamações revolucionárias, do setembrismo ao cartismo, do levante da M aria da F onte à proclamação da República em 1910, passando por todo o movimento dito regenerador, iniciado em 1851, o país vai de tropeço em tropeço até reencontrar o antigo ponto de equilíbrio na longa submissão à ditadura salazarista. M as, encerrada esta, com a R evolução dos C ravos de 1974, Portugal viu-se enfim claramente confrontado com a questão democrática, já não podendo confiar na tradicional solução macrocefálica. A reconstrução do venerando edifício nacional em ruínas há de fundar-se doravante, inevitavelmente, nos princípios da soberania popular efetiva e no respeito integral aos direitos humanos.

\section{0 caso brasileiro: democracia impossível?}

$\mathrm{N}$ a formação da sociedade brasileira, vemos reproduzidos e adaptados à realidade tropical os mesmos fatores que representaram, no Portugal metropolitano, um claro obstáculo à instauração da vida democrática. Tocqueville observou, em certa passagem de seu estudo sobre o antigo regime e a revolução francesa $^{32}$, que "é nas colônias que se pode melhor julgar da fisionomia do governo da metrópole, porque é aí que de ordinário todos os traços que a caracterizam se encontram ampliados e tornam-se mais visíveis".

Vejamos. 


\section{Soberania senhorial v. soberania estatal du rante o I mpério}

Foi no Brasil que, desembaraçado do ornamento feudal que o ataviava na metrópole, o regime do senhorio desenvolveu-se em toda a sua pujança.

Graças à farta distribuição de sesmarias, desde cedo despidas da obrigação de cultivo da terra, e à precoce organização da economia colonial no sentido da monocultura agrícola dirigida à exportação, o território brasileiro foi desde logo partilhado em grandes domínios rurais, cujos proprietários concentravam em sua pessoa a plenitude dos poderes, tanto de ordem privada, como política, assim os de natureza civil, como os de índole eclesiástica. Pode-se afirmar, sem risco de exagero, que do senhor dependia o presente e o futuro de todos os que viviam no território fundiário, fossem eles familiares, agregados, clientes ou escravos.

O sacerdote, representante oficial da I greja, não passava no grande domínio rural de um agregado doméstico, autorizado pelo senhor a celebrar missa, batizados e casamentos na capela da casa grande, bem como a sepultar os mortos no cemitério da fazenda.

A grande propriedade rural brasileira, que economicamente vivia em regime quase autárquico, era uma espécie de território soberano, onde o proprietário, como nos velhos senhorios europeus, fazia justiça e mantinha força militar própria, para defesa e ataque. Entre o senhor e as autoridades do Estado, como no plano internacional, estabeleciam-se relações de potência a potência, fundadas na conven ção bilateral de que o E stado se comprometia a respeitar a autonomia local do senhor, ao passo que este, como coronel da Guarda N acional ${ }^{33}$, obrigava-se a manter a ordem na região, emprestando à autoridade pública 0 concurso de seus homens de armas para a eventual guerra contra o estrangeiro, ou a episódica repressão aos levantes urbanos.

No meio urbano, justamente, a classe dos que se dedicavam ao grande comércio de exportação e importação, tanto quanto os principais banqueiros, atuavam em estreito relacionamento com o grande senhorio rural.

N uma análise linearmente marxista, dir-se-ia que o conjunto da máquina estatal nada mais seria do que o simples reflexo dessas classes dominantes, atuando sempre por conta e no benefício exclusivo delas. Em sentido diametralmente oposto, como foi sustentado por Raymundo Faoro ${ }^{34}$, a burocracia estatal, antes e depois da independência do país, formaria uma espécie de estamento weberiano, dotado de plena autonomia de mando.

A realidade, contudo, parece ter sido bem mais complexa do que esses esquemas unidimensionais supõem. E ntre as classes dominantes e o E stado, tanto antes, como depois de 1822, estabeleceu-se uma co-relação de forças, em que ambas as partes se confrontavam periodicamente, de modo aberto ou oculto, naquilo que o historiador J osé M urilo de Carvalho ${ }^{35}$, utilizando-se de uma expressão do sociólogo Guerreiro Ramos, denominou com razão a dialética da ambi güidade. $\mathrm{N}$ em as classes dominantes podiam impor quando quisessem a sua 
vontade ao Estado, nem este era livre de agir, como bem entendesse, contra 0 interesse econômico daquelas. D urante todo o seu longo reinado, D. Pedro II usou com prodigalidade do seu poder constitucional de "conceder títulos, honras, ordens militares e distinções em recompensa de serviços feitos ao Estado" (Constituição de 1824, art. 102, XI), para conquistar pessoalmente a lealdade das classes dominantes. Assim é que, do total de títulos nobiliárquicos outorgados durante o segundo reinado, 77\% foram de barão, sabendo-se que o baronato era reservado pelo imperador, quase que exclusivamente, aos grandes proprietários rurais e aos comerciantes de maior cabedal. Q uando, em 1888, o M inistério J oão Alfredo preparava-se para fazer votar a abolição da escravatura, ao sentir que se multiplicavam as defecções dos grandes senhores rurais do sudeste no apoio ao regime monárquico, ainda tentou em vão reter a lealdade do ConseIheiro Antonio Prado à Coroa, concedendo-Ihe o título de V isconde de São Paulo, por ele recusado.

M as por "Estado", como dito acima, em se tratando do Brasil imperial, deve-se entender mais exatamente o Poder Executivo e, dentro dele, como é óbvia, a figura do imperador. N este ponto, fomos e continuamos sendo legítimos herdeiros de Portugal. "É o traço saliente do nosso sistema político", enfatizou Joaquim $\mathrm{N}$ abuco a propósito da vida política no império, "essa onipotência do Executivo, de fato o Poder único do regime" ${ }^{36}$.

Seja como for, o resultado do confronto permanente entre os senhores locais e o governo central dava satiffação, ora a uma parte, ora a outra.

D urante toda a fase da monarquia imperial, o Estado logrou impor a sua vontade - sem dúvida laboriosamente, ao cabo de mais de meio século de esforços - em matéria de trabal ho escravo. $\mathrm{M}$ as no tocante ao regime da propriedade fundiária, o senhorio rural obteve plena satisfação de seus interesses. A Lei do Ventre L ivre de 1871 só pôde ser aprovada porque a Câmara dos D eputados era composta, em sua maioria, de funcionários públicos e magistrados, uns e outros estritamente dependentes do G overno. Já na votação da L ei de Terras, em 1850, as principais propostas governamentais, notadamente a criação do imposto territorial rural, foram derrotadas.

Em ambos esses episódios, como em todas as demais decisões legislativas que interessavam à nação como um todo, as classes inferiores foram tratadas como um elemento perfeitamente supérfluo do jogo político. O Brasil, observou um viajante francês no final do século XIX, dava a estranha impressão de um país desprovido de povo ${ }^{37}$.

\section{A primeira fase da "democracia republicana": 1889-1930}

Enquanto vigorou o regime monárquico, a democracia foi tida por todos, corretamente, como a antítese da autocracia. Por isso mesmo, a elite dirigente do país, a começar, escusa dizê-lo, pelo próprio monarca, considerou o regime democrático como uma clara subversão da ordem política. 
M enos de um ano após a independência, quando se elaborava a Constituição do novo Estado, o jovem imperador lançou, em proclamação datada de 19 de julho de 1823 "sobre o procedimento de várias câmaras", um brado de alerta:

Algumas Camaras das Provincias do N orte deram instruções aos seus Deputados, em que reina o espirito democratico. Democracia no Brazil! N este vasto, e grande I mperio é um absurdo; e não é menor absurdo o pretenderem ellas prescrever leis, aos que as devem fazer, comminando-Ihes a perda, ou derogação de poderes, que Ihes não tinham dado, nem Ihes compete dar.

Sem dúvida, o sistema de concentração do poder político no governo central, como emanação da vontade pessoal do imperador, foi um fator decisivo para que se lograsse vencer a tendência separatista, manifestada em várias regiões do país na primeira metade do século XIX, bem como para a defesa da nação contra o inimigo externo.

Finda a guerra do Paraguai, porém, e com a crescente prosperidade da cultura do café na região sudeste, as oligarquias rurais passaram a contestar 0 poder central e a reivindicar maior autonomia de atuação local, tanto no terreno econômico, como no político.

É a partir desse momento que a idéia de democracia, ou de república democrática, vê-se recuperada como fórmula política e purgada de suas conotações negativas. Em vez de favorecer a anarquia, apregoa-se, ela assegura o estabelecimento da ordem e dá mais eficiência à ação dos Poderes Públicos no plano local.

A palavra democracia e expressões cognatas, como solidari edade democrática, li berdade democrática, princípi os democráticos ou garantias democráticas, aparecem nada menos do que 28 vezes no M anifesto Republicano de 1870. U m dos seus tópicos é intitulado a verdade democrática.

U ma análise menos superficial do documento, no entanto, mostra que os próceres republicanos entendiam por democracia não exatamente o regime da soberania popular (expressão substituída, no M anifesto, por soberania nacional), mas sim a federação, tomado este conceito em sentido diametralmente oposto àquele com que fora empregado pelos constituintes de Filadélfia em 1787. Com efeito, federação, para os brasileiros, não queria dizer união de unidades políticas anteriormente soberanas, mas sim a descentralização de poderes num Estado unitário. $0 \mathrm{M}$ anifesto, aliás, encerra-se, segundo o estilo farfalhante da época, "arvorando resolutamente a bandeira do partido republicano federativo", e não a bandeira do partido republicano democrático.

O que, na verdade, constituía a razão de ser desse movimento descentralizador, o documento de 1870 fez questão de deixar na sombra: nenhuma palavra disse so bre aquilo que a elite política da época denominava, eufemisticamente, "a questão do estado servil".

O partido republicano paulista, contudo, não pôde prosseguir por muito tempo nesse jogo político sem abrir as cartas. N o manifesto lançado por ocasião do encerramento de seu congresso de 1873, os republicanos de São Paulo, evi- 
tando ladinamente uma tomada de posição sobre o mérito da questão, assim se pronunciaram:

Fique portanto bem firmado que o Partido R epublicano, tal como consideramos, capaz de fazer a felicidade do Brasil, quanto a questão do estado servil, fita desassombrado o futuro, confiado na índole do povo e nos meios de educação, os quaes unidos ao todo harmonico de suas reformas e do seu modo de ser hão de facilitar-Ihe a solução mais justa, mais pratica e moderada, sellada com o cunho da vontade nacional.

Parece que esta declaração seria sufficiente para apagar todas as duvidas. A questão não nos pertence exclusivamente porque é social e não politica: está no dominio da opinião nacional e é de todos os partidos, e dos monarchistas mais do que nossa, porque compete aos que estão na posse do poder, ou aos que pretendem apanhal-o amanhã, estabelecer os meios do seu desfecho pratico.

[...]

E ntretanto como quer que seja, se o negocio fôr entregue a nossa deliberação, nós chegaremos a elle do seguinte modo:

1 ㅇ - E $m$ respeito ao princípio da união federativa cada provincia realizará a reforma de accôrdo com os seus interesses peculiares mais ou menos lentamente, conforme a maior ou menor facilidade na substituição do trabalho escravo pelo trabalho livre.

2ㅇ - Em respeito aos direitos adquiridos e para conciliar a propriedade de facto com o principio da liberdade, a reforma se fará tendo por base a indemnização e o resgate.

O ito anos depois, ao discursar na Câmara dos D eputados, o republicano paulista Prudente de M orais, futuro Presidente da R epública, preferiu, em lugar de defender a introdução do regime republicano, propor a federalização do império, segundo o modelo alemão da época. U ma adequada distribuição de competências às províncias, argumentou, excluiria o perigo, que ele pressentia iminente, de que uma maioria de deputados, eleitos pelas províncias já desembaraçadas de escravos, impusesse a abolição da escravatura a to do o país ${ }^{38}$.

D errubada a monarquia, o Governo Provisório, em seu primeiro decreto de 15 de novembro de 1889, declarou proclamada "como forma de governo da N ação Brasileira a R epública Federativa", omitindo toda e qualquer referência à democracia.

O ra, enquanto o povo assistiu a tudo aquilo "bestializado", segundo a expressão famosa de Aristides L obo, as oligarquias locais, aparentemente vitoriosas no seu primeiro apelo aos quartéis, tiveram que atravessar alguns anos de grave incerteza e apreensão, diante do caráter centralizador e autoritário dos primeiros governos militares. 0 episódio repetir-se-ia, três quartos de século depois, com a derrubada do governo João Goulart. Com a diferença de que, nessa quadra política, o regime militar não durou apenas cinco, mas vinte anos. 
A Constituição de 1891 organizou, efetivamente, o Estado sob a forma federativa, como queriam os republicanos históricos. $M$ as no tocante à forma de governo, em lugar de seguir o alvitre parlamentarista do $\mathrm{M}$ anifesto de $1870^{39}$, preferiu instituir, segundo o modelo norte-americano, o sistema presidencial de governo.

O ra, o que parecia, a princípio, a mera reprodução da fórmula ianque, acabou por revelar-se, com o tempo, o regresso integral à velha tradição lusobrasileira, com a concentração maciça de to dos os po deres na pessoa do Chefe de Estado.

0 processo de retorno à macrocefalia estatal não se deu, porém, de um só golpe e sim em duas etapas.

D urante a primeira delas, que perdurou até 1930, o Presidente da República atuou como árbitro supremo das rivalidades entre os Estados federados, assim como cada Chefe do Poder Executivo estadual incumbia-se de arbitrar os conflitos entre os senhores locais. A chamada " política dos Governadores" desdobrava-se, pois, num pacto coronelista em cada unidade da federação. Em ambas as situações, estabelecia-se uma espécie de contrato político bilateral. No plano da federação, o Presidente da R epública comprometia-se a dar mão forte aos governos estaduais, desde que estes sufragassem o candidato à sucessão presidencial indicado por ele próprio, Presidente. No plano estadual, os senhores rurais, atuando ou não, oficialmente, como coronéis da Guarda N acional, faziam sempre dos candidatos governistas os vencedores dos pleitos eleitorais, obrigando-se os Governadores, em contrapartida, a garantir, mediante o concurso da Polícia, da M agistratura e do M inistério Público, a soberania de cada senhor no território de sua propriedade ${ }^{40}$.

Analisada, assim, em toda a sua crueza, é preciso reconhecer que a "democracia federativa" estabelecida pela R epública Velha estava longe de ser o "Iamentável mal-entendido" de que falou Sérgio Buarque de $\mathrm{H}$ olanda. A elite política da época jamais se deixou iludir sobre o sentido real dos conceitos de soberania popular ou de direitos de cidadania. A retórica democrática, nos seus escritos e discursos, não passava de grosseiro disfarce ideológico.

Esse equilíbrio sinalagmático entre as oligarquias locais e o poder central, à revelia do povo, foi afinal vencido, não de dentro, mas de fora, com o advento da depressão econômica mundial desencadeada pela quebra da Bolsa de N ova York em 1929. 0 setor de exportação de produtos primários, no campo e nas cidades, duramente golpeado pela crise, retirou seu apoio a ambos os pactos, o estadual e o federal, e o sistema político veio abaixo.

\section{A vatares da "democracia republicana" a partir de 1930}

A marginalização, que se acreditava temporária, das classes dominantes ligadas à agricultura de exportação, deixou o Estado brasileiro como ator único na cena política. O ra, após a revolução de 1930, o aparelho estatal submeteu-se ao 
poder incontrastável do chefe do governo provisório, rapidamente legitimado como Presidente da R epública. I nvestido nessa posição, o novo C hefe de E stado pôs desde logo em marcha, com a política de industrialização substitutiva de importações, um processo de reestruturação das posições de mando na sociedade brasileira, ao criar de toutes pièces uma nova classe dominante: o grupo dos empresários industriais.

0 restabelecimento do confronto político entre Estado e sociedade civil, ou, se se quiser, segundo os conceitos da análise gramsciana, entre o grupo hegemônico e a classe dominante, fez-se, porém, com um acréscimo de monta: 0 Chefe de Estado criou junto à nova classe industrial, como delegado pessoal dele, Presidente da República, o também novo setor do sindicalismo oficial.

O povo, to davia, continuava a ser o que sempre fora: o grande ausente. Sua entrada em cena só viria a dar-se com a queda do ditador em 1945, seguida da reconstitucionalização do Estado no ano seguinte. Iniciou-se, então, um novo jogo político, caracterizado agora pelo regular funcionamento daquilo que um largo setor da intelectualidade considerava e ainda considera como a quinta essência da democracia: separação oficial entre os Poderes do Estado, eleições livres e pluralidade partidária.

$\mathrm{N}$ ão é difícil demonstrar que, em países afetados por uma abissal desigualdade, como é o caso do Brasil, o cumprimento formal desses rituais democráticos nada tem que ver com a efetiva soberania popular e o integral respeito aos direitos humanos.

Seria, contudo, um grave erro de análise pretender que o povo, quando chamado a eleger periodicamente seus representantes, figura como elemento meramente passivo no quadro geral da ação política. Da mesma forma que a dominação social de classe não significa, ipso facto, o controle absoluto do apareIho estatal, assim também a aliança da classe dominante com a elite dirigente no E stado tampouco significa uma manipulação mecânica do voto popular nas eleições. Por mais eficazes que sejam hoje os méto dos de direção da opinião pública, subsiste sempre um grau mais ou menos elevado de incerteza nas decisões eleitorais. 0 sistema é, portanto, deficiente, quer para levar, por si só, o povo ao exercício do poder soberano em seu benefício, quer para garantir a plena satisfação dos interesses das classes dominantes.

Foi, sem dúvida, essa incerteza ínsita em todo regime de democracia formal que levou as classes dominantes nacionais, apoiadas pelo governo norteamericano, a suspender, a partir de 1964, o funcionamento do sistema. Ele só veio a ser recomposto, ao ser promulgada, em 1988, com a Constituição atualmente em vigor. M as, então, o quadro mundial já se achava inteiramente modificado, com o rápido avanço do processo de globalização capitalista. Em todos os países da chamada periferia do globo, os do is agentes tradicionais da política - 0 Estado nacional e as classes dominantes internas - foram singularmente enfraquecidos, senão afastados de todo. 
Restou, pois, o povo, em função do qual - não se esqueça - foi cunhada há vinte e cinco séculos, na G récia, a denominação clássica do regime político. Saberá o povo, hoje, assumir o efetivo exercício daquele poder supremo sobre todos os cidadãos (to kurion tôn pol eôn) ${ }^{41}$, que a teoria Ihe reserva?

É o que se passa a conjecturar per summa capita, à guisa de conclusão.

\section{C onclusão}

Como vimos na primeira parte desta exposição, Aristóteles considerava a democracia como corrupção do regime político em que o conjunto dos cidadãos exerce a soberania em função do bem comum (pros to koinon supheron), regime esse que, à míngua de denominação específica, ele preferiu chamar pelo gênero "organização da cidade" (politéia). A corrupção democrática consistiria no exercício do poder supremo pela maioria pobre em seu exclusivo benefício.

O ra, a realização do bem comum do conjunto dos cidadãos supõe a eliminação da desigualdade social no tocante às condições de uma vida digna, entendida esta como o comum respeito ao conjunto dos direitos humanos, tanto os de natureza civil e política, como os de ordem econômica, social e cultural. Se a justiça é fundamentalmente uma relação de igualdade, a sua realização social corresponde, como é óbvio, à supressão de toda desigualdade preexistente.

Segue-se daí que a ação política dirigida a elevar as camadas mais carentes do povo, de forma a equipará-las, em matéria de direitos humanos, às classes mais ricas e poderosas, vai claramente no sentido do bem comum.

$\mathrm{N}$ a verdade, o critério mais adequado para a classificação dos regimes políticos não parece ser o do número de sujeitos que exercem a soberania, como pensaram os clássicos, mas sim o da finalidade objetiva com que esta é exercida. De acordo com este critério, a verdadeira essência da democracia consiste na ação prioritária dos Poderes Públicos em favor das classes pobres e dominadas, ou seja, a realização sistemática da justiça proporcional (to dikáion análogon), como a denominou Aristóteles ${ }^{42}$, na qual os que têm menos recebem mais e vice-versa.

Com efeito, numa sociedade marcada por profundas desigualdades de nível e de qualidade de vida, o conjunto dos mais pobres não se acha em condição de exercer autonomamente os seus direitos de cidadania. $\mathrm{N}$ o caso brasileiro, essa situação é ainda mais grave, em razão da tradicional carência de coesão social no seio do povo ${ }^{43}$, oriunda, como vimos, da persistente dominação senhorial, desde os tempos medievais em Portugal. As classes social e economicamente dominadas encontram-se numa situação semel hante à das pessoas juridicamente incapazes para o exercício dos atos da vida civil: elas carecem de proteção legal, pela designação de pessoas ou órgãos incumbidos de exercerem, em seu nome e benefício, os poderes inerentes aos seus direitos subjetivos.

Tal significa dizer que a ação política prioritária em favor dos fracos e pobres, numa autêntica democracia, supõe a existência de um Estado forte e bem 
organizado, constitucionalmente competente para impor a sua vontade às classes dominantes no interior do país e às potências dominantes no plano internacional. O u seja, exatamente o oposto do Estado subserviente, engendrado pelo atual capitalismo globalizante.

Ao contrário do que postula uma certa análise marxista, como assinalado acima, o poder das classes dominantes nunca chega a anular completamente a autonomia dos órgãos estatais. E é bem por isso que, em sua maior parte, os golpes de E stado contemporâneos têm sido fomentados pelas classes ou grupos economicamente fortes, com o oportuno auxílio dos agentes do poder capitalista internacional.

Todavia, como ninguém ignora, o fortalecimento imprudente do poder estatal acaba fatalmente por suscitar o despotismo, com a supressão das liberdades civis e políticas.

U ma solução para esse dilema poderia ser encontrada a partir do princípio fundamental de que a função precípua do Estado, numa democracia, consiste no amparo econômico e na formação cívica das classes e grupos mais pobres do país, a fim de que eles se tornem capazes de exercer, de modo pleno e autônomo, a sua cidadania.

Essa ação pedagógica dos governantes, tão enfatizada por Aristóteles no último livro da Política, obedeceria a duas diretrizes.

De um lado, a ampliação da competência dos órgãos estatais, cujo preenchimento não está sujeito à influência direta das classes dominantes, como 0 Judiciário e o M inistério Público, para que eles imponham ao Executivo e ao L egislativo a elaboração e aplicação de políticas públicas destinadas à realização dos direitos econômicos, sociais e culturais.

De outro lado, a criação de instâncias de participação popular obrigatória no funcionamento do Estado, em todos os níveis, fundadas logicamente no pressuposto da prévia aprovação por referendo da C onstituição e suas emendas. São exemplos dessa participação ativa dos cidadãos no exercício do governo a autorização popular para a tomada de decisões políticas de longo e profundo alcance, como a celebração de tratados internacionais instituidores de zonas de livre comércio ou mercado comum; a desoligarquização do sistema el eitoral, mediante a aprovação, por referendo po pular, das suas linhas diretrizes; o controle so cial dos meios de comunicação de massa; a elaboração conjunta de orçamentos com os órgãos de representação popular; a ampla legitimação de agir em juízo atribuída a associações civis, na defesa dos direitos econômicos, sociais e culturais; o reforço da ação popular cível e a reintrodução da ação popular criminal|4 ; a dissolução por sufrágio popular de assembléias parlamentares, ou a destituição pelo mesmo mecanismo de chefes do Poder Executivo.

E m suma, a civilização humanista com que sonhamos não pode contentarse com o medíocre programa de fazer da democracia o menos mau dos regimes 
políticos. Seria um escárnio se os espíritos autenticamente democratas se conformassem, hoje, com a supremacia mundial do sistema capitalista, reservando aos Estados nacionais e às organizações internacionais humanitárias, tão só, a tarefa ancilar de pensar as chagas que esse sistema de exploração econômica abriu na humanidade. A missão política que nos incumbe é bem outra, muito mais exaltante: trata-se de construir um mundo novo, em que todos os seres humanos, em qualquer parte do globo terrestre em que se encontrem, possam, enfim, nascer e viver, livres e iguais em dignidade e direitos.

N otas

1 M ontesquieu, Del'esprit deslois, livro VIII , cap. 2.

2 J ames M adison, The Federalist, no 10.

3 H uman D evelopment R eport 2002 - D eepening Democracy in a Fragmented World, O xford, O xford U niversity Press, p. 1.

4 Platão, R epública, livro I, 338 d.

5 Platão, O Político, 302 c e ss.; Aristóteles, A Política, 1279 a, 25 e ss.

6 I dem, 1279 b, 11 e ss. No mesmo sentido, sempre na Política, 1281 a, 12-19; 1289

b, 29-32; 1290 a, 30; 1290 b, 20; 1291 b, 2-13; 1296 a, 22-32; 1296 b, 24-34; 1315

a, 31-33; 1317 b, 2-10; 1318 a, 31-32.

7 Aristóteles, A Política, 1289 a, 40.

8 Xenofonte, M emoriabilia, IV, 1, 3.

9 I dem, 1289 b, 5.

10 I dem, 1293 b, 34-41.

11 I dem, 1290 b, 1.

12 Guy Fourquin, Senhorio e Feudalidade na I dade M édia, Lisboa, Edições 70, p. 12.

13 Philippe de Beaumanoir, Coutumes de Beauvaisis, ed. por Am. Salmon, t. 2o , Paris, Alphonse Picard et Fils, 1900, no 1043.

14 Cf. M arc Bloch, A Sociedade Feudal, 2a ed., Lisboa, Edições 70, p. 254.

15 Vejam-se as judiciosas considerações feitas pelo grande historiador português J osé M attoso, I dentificação de um País - Ensai o sobre as origens de Portugal, t. I, 5aㅡ ed., Lisboa, Referência/ Editorial Estampa, pp. 224 e ss.

$16 \mathrm{Cf}$. D a existencia ou não exi stencia do feudalismo em Portugal, in O púsculos, tomo V, Controvérsias e estu dos históricos, tomo II, 4aa ed., Lisboa Rio de Janeiro, Bertrand/ Francisco Alves, pp. 189 e ss.

17 Cf. M ichel I. Rostovtseff, H istoire économique et sociale de l'empire romain, Paris, Robert Laffont, 1988, pp. 165-166.

18 J osé M attoso, op. cit., t. I, pp. 260-261.

19 J. Lúcio de Azevedo, Épocas de Portugal Económico - Esboços de história, 4ạ ed., Lisboa, Livraria Clássica Editora, p. 18.

20 Idem, p. 20. 
21 I dem, p. 32.

22 I dem, p. 165.

23 Sérgio Buarque de H olanda, R aízes do Brasil, 5a ed., Livraria osé Olympio, Rio de Janeiro, p. 11.

24 Cf. J. Lúcio de Azevedo, op. cit., pp. 70 ess.

25 I dem, p. 74.

26 É a tese sustentada por Luiz Felipe de Alencastro, em 0 trato dos viventes- formação do Brasil no A tlântico Sul, séculos XVI eXVII, São Paulo, Companhia das Letras.

27 J . Lúcio de Azevedo, op. cit., p. 82.

28 Citado por C. R. Boxer, The Golden A geof Brazil, 1695 -1750, U niversity of California Press, 1962, p. 393, nota 4 ao capítulo V.

29 Sermão da Visitação de N ossa Senhora, in Sermões, Porto, Lello \& I rmãos, 1951, vol. IX, p. 346.

30 Cf. C. R. Boxer, The Por tuguese Seaborne Empire 1415-1825, Carcanet, em associação com a Fundação Caloute Gulbenkian e a Comissão O s D escobrimentos, L isboa, 1991, p. 328.

31 Sérgio Buarque de $\mathrm{H}$ olanda, op. cit., p. 119.

32 Aléxis de Tocqueville, L'A ncien R égime et la R évolution, Paris, Gallimard, 1952, p. 286.

33 A G uarda N acional, criada por lei de 18 de agosto de 1831 como auxiliar do Exército, foi uma revivescência da antiga corporação das ordenanças, existente durante a época colonial. Todos os cidadãos brasileiros maiores de dezoito anos eram obrigatoriamente inscritos na Guarda N acional. A corporação tornou-se, no final do império, meramente decorativa ou honorífica. Sobre o assunto, cf. Victor N unes Leal, Coronelismo, Enxada e Voto, 3a ed., 1976, pp. 211 e ss.

34 Raimundo Faoro, OsD onos do Poder - A formação do patronato político brasileiro, 3 a ed., São Paulo, Globo.

35 J osé M urilo de Carvalho, I - A Construção da Ordem, II - Teatro deSombras, 2ª ed., Rio de J aneiro, UFRJ/ Relume Dumará.

36 J oaquim de $\mathrm{N}$ abuco, U m Estadista do I mpério, Rio de J aneiro, N ova Aguilar, Biblioteca L uso-Brasileira, Série Brasileira, p. 239.

37 "La situation fonctionnelle de cette population peut se résumer d'un mot: le Brési n'a pasdepeuple". A pud G ilberto Freyre, Casa Grande\& Senzala, 34a ed., Rio de J aneiro e São Paulo, Record, p. 35.

38 Cf. Robert Conrad, Osúltimosanosda escravatura no Brasil, 2a ed., Rio de J aneiro, Civilização Brasileira, p. 267.

39 “A soberania nacional só póde existir, só póde ser reconhecida e praticada em uma nação cujo parlamento, eleito pela participação de todos os cidadãos, tenha a suprema direcção e pronuncie a ultima palavra nos publicos negocios."

40 Veja-se a monografia, ainda insuperada, de V ictor $N$ unes L eal, citada na nota 29.

41 Aristóteles, A Política 1279 a, 27-28.

42 Ética a N icômaco 1131 a, 29-30. 
43 Cf. Sérgio Buarque de H olanda, op. cit., cap. I; Caio Prado J r., Formação do Brasil Contemporâneo, 16a ed., São Paulo, Brasiliense, pp. 341 e ss.

44 Deve-se lembrar que a Carta Política de 1824 admitia que "por suborno, peita, peculato e concussão", pudesse ser intentada contra os juízes ação popular, "pelo próprio queixoso, ou por qualquer do Povo" (art. 157).

Fábio K onder C omparato é professor-titular da Faculdade de Direito da U SP. D outor em $\mathrm{D}$ ireito da U niversidade de Paris e $\mathrm{D}$ outor $\mathrm{H}$ onorisC ausa daU niversidade de C oimbra. 